\title{
NEGATIVE EFFECTS OF ELECTRONIC MEDIA (ESPECIALLY TV) ON CHILDREN AND YOUTH
}

\section{René SZOTKOWSKI}

\begin{abstract}
The negative effects of electronic media, particularly of TV, on individuals are becoming more obvious nowadays. The electronic media influence individual's values, emotions, conscience - so called superego etc. This brief article discusses the most serious effects the inapt usage of electronic media has on present-day children and youth.
\end{abstract}

Key words: media, electronic media, TV, children and youth, educational technological device.

\section{NEGATIVNÍ PŮSOBENÍ ELEKTRONICKÝCH MÉDIÍ (ZEJMÉNA TELEVIZE) NA SOUČASNÉ DĚTI A MLÁDEŽ}

Resumé: Negativni účinky elektronických médií, zvláště pak televize, na lidského jedince jsou stále více patrné. Elektronická média působi na jeho hodnotový systém, emočni sféru, svědomi- tzv. superego aj. Př́spěvek stručně pojednává o nejzávažnějšich vlivech na současné děti a mládež, které s sebou přináši nevhodné využiváni elektronických médii, resp. televize.

Klíčová slova: média, elektronická média, televize, dèti a mládež, technický výukový prostředek

\section{Úvod}

Informační a komunikační technologie, internet, satelitní a kabelové televize, domácí video a videohry, multimediální aplikace apod., jsou neodmyslitelnou součástí našeho běžného života. Audiovizuální informace, jež jsou reprodukovány prostřednictvím těchto médií, nás, aniž si to dostatečně uvědomujeme, do značné míry ovlivňují. Patrně nejvíce lze pozorovat vliv těchto médií na současné děti a mládež, jež podstatnou část svého volného času tráví u počítače či sledováním televizních programů. Právě zmiňovaná televize stále zaujímá podle většiny provedených studií roli vedoucího média, a to $\mathrm{i}$ přes masový rozvoj internetu a dalších mediálních nosičů a s nimi spojených možností (internetu náleží druhé místo za sledováním televize).

Pro ilustraci lze uvést studii Duspivy, Z. (1) z roku 2003, který poukazuje na čas strávený sledováním televize u mládeže od 10 do 18 let. Mládeži v tomto věku zabírá sledování televize průměrně 120 minut denně! $Z$ této doby přibližně $11 \%$ zabírá reklama.

Alarmující je zejména fakt, že děti nejsou žádnými minoritními televizními diváky, vždyt' osoby mladší 18 let tvoří dnes okolo $37 \%$ světové populace (televizní přijímač je součástí takřka $8 \mathrm{z}$ deseti světových domácností).

\section{Elektronická média}

Výše jmenovaná média patří mezi tzv. elektronická média, jimiž podle Vachtla, P. (2) všeobecně rozumíme jakékoli prostředky sdělovací techniky, jež použivají po fyzikální stránce pohyb elektronů, resp. elektromagnetické pole. Do této kategorie médií lze zařadit široké spektrum technických zařízení, která byla $\mathrm{v}$ minulosti prezentována zejména rozhlasem, telegrafem, analogovou televizí, páskovými videomagnetofony aj. Současná doba je charakteristická elektronickými médii jako jsou např. digitální a počítačové elektronické technologie, internet, mnohokanálové satelitní a kabelové televize, domácí video a videohry, multimediální DVD, CD-ROM apod.

Přesná charakteristika elektronických médií je dosti složitá. Lze pouze konstatovat, že veškerá moderní elektronická média mají jedno společné a tím je zprostředkování určitého druhu audiovizuálních informací. Velmi výstižně popisuje elektronická média McLuhan, M. (3), podle něj el. média vytvárí nové a bezprecedentní sociální situace, v nichž navazujeme vztahy a předvádíme se, aniž bychom byli svázáni př́íslušností ke konkrétní fyzické nebo společenské lokalitě. Díky - nebo kvůli - elektronickým médiím se nacházíme všude a současně nikde. Elektronická média, která nás oslovují především obrazy a zvuky, nejsou před nikým "uzamčena" abstraktním 
kódem vyžadujícím různé úrovně gramotnosti, jako je třeba písmo. Dovolují vstoupit dovnitř prakticky každému, což s sebou však nese také zánik tajemství. Nastolují "smíšené situace", v nichž se dřrive neznámé a pouze tušené stává běžně dostupným.

\section{Negativa elektronických médií}

Negativní působení elektronických médií (zejména televize) na děti a mládež jsou obecně známa. Negativa lze zpravidla rozdělit na 2 oblasti:

a) viditelné a žretelné obsahové vlivy (obsažené $\mathrm{v}$ pořadech rozhlasu a televize) - zde je možno uvést všudypřítomné násilí, zločin, surovost, loupeže, střelbu do lidských těl, v mnoha prípadech sex. Tyto fenomény postupně pronikají do dětských televizních programů, čímž neblaze působí na utváření jejich svědomí, tzv. superega. Naše svědomí, které nás odrazuje od společensky nežádoucího jednání, přestupků či zločinů, se totiž vytváríi $\mathrm{v}$ raném dětském věku. Je tedy velmi pravděpodobné, že pokud vystavíme děti již v ranném dětství působení nevhodného televizního vysílání, záporných, ale i kladných filmových hrdinů, existuje reálné nebezpečí útlumu, v horším prrípadě zničení dětského svědomí. Tyto argumenty dle Kalhouse, Z. a Obsta, O. (4) potvrzuje fakt, že základní náplň volného času dětí, které se dopouštějí trestného jednání, je sledování televize. Kurátoři dětí a mládeže upozorňují na změny, knimž sledování televizních pořadů významně přispívá. V oblasti trávení volného času je patrný významný posun do pasivních rovin. Hodnotový systém dětí a mládeže je výrazně orientován na peníze, na jejich rychlé a bezpracné získání i za cenu přestoupení zákonů. Dochází ke ztrátě vyšších společenských citů, s čímž souvisí četný výskyt úzkostných stavů. Emoční sféra je prostá soucitu, ochota pomoci je považována za projev slabosti.

b) cílené ovlivňování diváka - vědomá i podprahová reklama (dále jako mediální modely). O vlivu reklamy na člověka, potažmo na dětského diváka, bylo napsáno již mnohé. O reklamě je možné říci, že je všudypř́ítomná. Televizní pořady jsou reklamou prokládány, v časopisech na nás zhližži obrázky krásných modelek, na billboardech se předvádějí usměvaví mladí lidé a nabízejí služby své společnosti. Reklama nás ovlivňuje způsobem, který je těžce popsatelný, zrádný a jehož vlivu se lze jen těžko ubránit. Zvláště patrný je vliv reklamy na dětského diváka. Vzbuzuje u dětí chut', touhu produkt obsažený $\mathrm{v}$ reklamě vlastnit. Reklamy dětem ukazují, co je v současné době aktuální, co má každý, kdo chce být součástí št’astného kolektivu vrstevníků. Pokud sami nemají dost finančních prostředků, pak působí na rodiče či prarodiče, aby produkt koupili. Reklama také formuje a posiluje jejich vztah ke značce, jejich vkus, systém hodnot. Ochrana před nežádoucími vlivy reklamy je sice řešena formou spec. zákonů jako je např. zákon o rozhlasovém a televizním vysílání a zákon o regulaci reklamy, ovšem je velmi obtížné mediální systém jakkoli regulovat, jelikož není zcela přesně definován škodlivý mediální vliv reklamy na děti.

Výše uvedený výčet negativních vlivů není $\mathrm{v}$ žádném případě konečný. Zmínit zde veškerá negativa by bylo však nad rámec tohoto př́spěvku. Abychom byli korektní, je třeba uvést i některá pozitiva, jež elektronická média bezesporu přináší.

\section{Televize v procesu edukace}

Jistá pozitiva elektronických médií lze spatřovat $\mathrm{v}$ prrípadě jejich využití $\mathrm{v}$ edukační realitě. Tato technika je schopna $v$ podobě technických výukových prostředků, celkovou koncepcí i technickým řešením, realizovat značnou část pedagogických požadavků na zvýšení efektivity lidského učení. Stále více umožňuje přenos informací, a to $\mathrm{v}$ obou směrech - od učitele $\mathrm{k}$ žákovi i od žáka $\mathrm{k}$ učiteli. Zefektivněné vyučování se děje podle Geschvindera, J. (5) především využitím tzv. vícekanálového vnímání, zpětné vazby a zvýšenou motivací.

V systému technických výukových prostředků má své významné místo televize. V době, kdy ještě nebyly multimediální počítače rozšířeny $\mathrm{v}$ takovém měřítku, jako je tomu nyní, patřila televize ve spojení s videorekordérem, $\quad \mathrm{k}$ nejrozšířenějšímu technickému výukovému prostředku. Pro tuto techniku byla zpracována celá řada speciálních videopořadů pro jednotlivé předměty, které jsou na mnohých školách dodnes hojně využívány. V současnosti se televize použivá stále více ke zřizování archivů televizních pořadů vhodných pro výuku.

V souvislosti s výše uvedenými pozitivy nesmíme zapomenout na podstatný klad technických výukových prostředků - na 
názornost, resp. na uplatňování zásady názornosti.

Zásada názornosti je dle Dostála, J. (6) jedním ze základních pedagogických principů moderního vzdělávání. Její uplatnění nalezneme $\mathrm{v}$ nejrozmanitějších formách $\mathrm{v}$ celém výchovněvzdělávacím procesu. Nejlépe tuto zásadu charakterizuje jisté čínské př́isloví, které říká, že vidět znamená zapomenout, vidět a slyšet znamená znát, vidět, slyšet a dělat znamená umět (4).

\section{Závěr}

Závěrem lze pro zajímavost či zamyšlení zmínit knihu The Mysterious Events od P. J. Franka (7). Seznamujeme se v ní s jistým italským podnikatelem, který založil politickou stranu Vzhưru, Itálie. Toužil po tom, dostat se k politické moci a také se mu to podařilo. Proč? Protože vlastní několik televizních stanic, jež vytváríi a upevňují veřejné mínění.

Tento člověk je št'astně ženatý a má několik nadaných dětí, o něž pečují chůvy, soukromí učitelé, služebnictvo, osobní strážci. Všichni společně žijí $v$ préepychové vile s velkou zahradou, několika bazény, garážemi...

Pouze jediná technická vymoženost dnešní moderní civilizace $\mathrm{v}$ tomto honosném obydlí s šesti ložnicemi chybí. Není to nic jiného než obyčejná televize, ona bedýnka $\mathrm{s}$ barevně se míhající obrazovkou.

Velice podivná skutečnost. Televizi totiž nesmí sledovat ani pánovo služebnictvo. Jediný televizní přijímač má pouze pán domu uzamčený ve své pracovně ve skříni, která plní funkci bezpečného trezoru.

Podnikatel, o němž hovoříme, je v současné době již vrcholovým politikem a vládcem nad veřejným míněním. Jeho televizní stanice „chrlí“ na Italy od rána do večera nejrůznější informace a přsesvědčují je o tom, co si mají myslet, co mají jíst a pít. Majitel nádherného zámečku svému národu diktuje, co se mu má a musí líbit, jakým způsobem má žít, koho má ve volbách zvolit, jaká móda či parfém je žádoucí, aby byli potomci starých Ř́manů přitažliví. Přesto tento známý televizní magnát, který na televizi vydělal množství peněz, rozhodl, že jeho potomci nesmí přijít s jejími magickými účinky jakkoli do styku, jakoby právě tato nevinná bedýnka $\mathrm{s}$ jejím blikajícím obsahem byla nejnakažlivějším duševním morem...

\section{Literatura}

(1) DUSPIVA, Z. Vliv elektronických médií na děti a mládež ČR v roce 2003. Britské listy [online]. 2003 [cit. 2009-01-26]. Dostupný z WWW:

$<$ http://www.blisty.cz/2003/8/20/art15104.html $>$. ISSN 1213-1792.

(2) VACHTL, P. Iracionalita a dezinformace v dnešních elektronických médiích. Sisyfos [online]. 2006 [cit. 2009-01-26]. Dostupný z WWW:

$<$ http://www.sysifos.cz/index.php?id=vypis\&se $\mathrm{c}=1161531085>$.

(3) MCLUHAN, M. Essential McLuhan (Člověk, média a elektronická kultura). Brno : Jota, 2000. 415 s. ISBN 80-7217-128-3.

(4) KALHOUS, Z., OBST O. Školni didaktika. 1. vyd. Praha : Portál, 2002. ISBN 80-7178253-X.

(5) GESCHWINDER, J. a kol. Metodika využití materiálních didaktických prostredků. 1. vyd. Praha : SPN, 1987. ISBN nemá.

(6) DOSTÁL, J. Učební pomi̊cky a zásada názornosti. 1. vyd. Olomouc : Votobia, 2008. ISBN 978-80-7409-003-5.

(7) JONES, P. F. The Mysterious Evens (Tajemné síly). Liberec : Dialog, 1995. 160 s. ISBN 80-85843-44-7.

(8) MEYEROWITZ, J. No Sense of Place: The Impact of Electronic Media on Social Behaviour (Všude a nikde: vliv elektronických médii na sociální chování). Praha : Karolinum, 2006. 341 s. ISBN 80-246-0905-3.

Mgr. René Szotkowski, Ph.D.

Katedra pedagogiky s celoškolskou působností

Pedagogická fakulta Univerzity Palackého

Žižkovo nám. 5

77140 Olomouc

Tel.: 585635178

E-mail: rene.szotkowski@upol.cz www pracoviště: www.kpg.cz 